GEOGRAFICKÝ ČASOPIS / GEOGRAPHICAL JOURNAL 73 (2021) 1, $21-41$

DOI: https://doi.org/10.31577/geogrcas.2021.73.1.02

\title{
CHANGES IN SECTORAL STRUCTURE AND SPATIAL DISTRIBUTION IN EUROPE: WHERE HAS THE DE-INDUSTRIALISATION PROCESS STALLED?
}

\author{
Oto Hudec*, Žofia Sinčáková* \\ * Technical University of Košice, Faculty of Economics, Department of Regional Science and Management, \\ Němcovej 32, 04001 Košice, Slovakia, \\ oto.hudec@tuke.sk, zofia.sincakova@tuke.sk
}

\begin{abstract}
Changes in sectoral structure and spatial distribution in Europe: Where has the de-industrialisation process stalled?

De-industrialisation in Western countries in the second half of the 20th century has been a manifestation of the post-industrial era when jobs have increasingly moved from the primary and secondary sectors to services and knowledge-intensive sectors. The significant spatial relocations can be explained as the result of manufacturing path dependence and the internationalisation strategies of the largest industrial manufacturers. Therefore, the main goal of the article is to identify the sectoral changes in the secondary and knowledge-intensive sectors over the past 20 years and the spatial concentrations of industrial production in the European Union area. The new Index of Sectoral Specialisation is proposed to verify the hypothesis that evolution brings about structural changes, the decline of older sectors and the promotion of new ones. The relationship between the economic advancement of a country and the economic structure set in higher sectors has been demonstrated. However, several regions and countries still maintain a higher level of manufacturing and this delayed de-industrialisation progress is evident in a relatively compact area in Central Europe. This raises the question of whether remaining in industrial employment can still be an advantage for some regions. The analysis has shown industrial regions in Germany, Central and Eastern Europe to be more resilient, as they recovered more quickly from the world financial crisis in 2007 compared to the regions dominated by the service sector.
\end{abstract}

Key words: sectors of the economy, manufacturing, structural change, Central and Eastern Europe

\section{INTRODUCTION: DE-INDUSTRIALISATION IN THE EUROPEAN UNION}

The significant changes in global industrial organisation in recent decades can be explained as the integration of trade accompanied by the disintegration of production (Gereffi et al. 2005). The primary driver of increasingly fragmented production across geographic space has been the expansion of transnational companies (TNC) through foreign direct investments (FDI) (Pavlínek and Žížalová 2014). All regions and countries have become part of broader industries (Sturgeon et al. 2008) within elaborate borderless production systems significantly driven by TNCs. This reorganised international division of labour invokes debates about the impacts of globalised value chains on reshaping economic structures and geographic shifts of economic sectors in space. Today, these fragmented and modularised activities are integrated by invisible threads within global value chains which are subsequently reflected in the concentration of economic activities and regional specialisation.

However, it is not only spatial movements stimulated by the emergence of global value chains which have changed the world geography of specialisation. The parallel effect of de-industrialisation shook up the sectoral profiles of regional economies fundamentally when balanced productivity growth in manufacturing had been ex- 
hausted. Jobs in industrial production had to be replaced by the service sector. The post-war "golden age" of productive employment gradually came to an end in Western Europe in the late 1960s. The slump in manufacturing labour in the 1970s and 1980s brought severe social dislocations and shocks (Hall 1993). Therefore, it is tempting to return to the topic and empirically examine the steadiness of the deindustrialisation trend in European countries.

Moreover, de-industrialisation can be spoken of as an expected stage in economic development. Most agrarian societies experienced commercial and industrial revolution from the 18th century, representing a fundamental change in the world economy (Tamura 2002). The contemporary post-industrial society is the result of a second shift from industrial production to the service and knowledge industries. The structure of demand from production to services has gradually changed, and the rapidly growing tertiary sector has become an active component of productbased value chains. However, understanding its role in value chains is lacking due to its intangible nature and heterogeneity (Low 2013). The three-sectoral theory retains its dominance in overall thinking about the structure of an economy, but services are increasingly problematic to fit into one sector. As such, there is growing pressure to distinguish between different service activities (Herrendorf et al. 2013) in addition to capturing the new substance of economic advancement (Jorgenson and Timmer 2011). One of the most rational approaches is to consider the knowledge-intensive sector (KIS) separately (Isaksen and Onsager 2010).

Many different factors that cause or contribute to de-industrialisation in mature economies have been discussed in the literature (Tregenna 2009). These range from the reclassification of jobs from production to services due to outsourcing activities; slower employment growth in manufacturing due to higher productivity growth in manufacturing than in services; globalisation and the negative effects of international trade, especially imports from lower-cost producers. Although there are various factors considered in de-industrialisation and structural change, Fisher, Clark and Kuznets postulate in their works that sectoral structure changes with the development of economies (Syrquin 2008 and Van Neuss 2018). Industries with a growing share of aggregate production coexist with declining industries where each industry goes through a cycle of growth, maturity and stagnation. Towards the end of the 20th century, highly industrialised regions were often perceived as structurally backward and heading towards economic decline. More developed countries are also at the forefront of innovation and undergo structural changes before the less developed ones. In the last three decades, the service sector has been growing rapidly, including new knowledge-intensive services that support the growth of living standards in advanced economies. It is generally believed that there is a significant association between lower GDP per capita and the backward structure of a regional economy (Hamilton 2017).

However, there is also a stream of literature that is sceptical about the growth of services and still places a key role on industrial production (Tregenna 2009). Some even go as far as to consider de-industrialisation as the reason for secular stagnation or low economic growth of advanced economies. Therefore, it seems that looking at the changes in economic structure in the European context, emphasising the possible key role of industrial production in some countries and regions of Europe, is an essential topic. In addition to economic growth, supporting a high share of industrial production could be an important topic of economic policy due to the importance of resilience to external shocks. 
Indeed, while these sectoral and spatial changes highlight the evident shift towards the third and knowledge-intensive sectors in most western countries, there is still a group of European countries where the de-industrialisation process has stalled. These countries continue to keep noteworthy levels of employment in manufacturing. As is already known, de-industrialisation in developed countries is also linked to deteriorating competitiveness in labour-intensive industries; or vice versa with the comparative advantage of developing countries (Alderson 1999). Due to the differences in economic maturity, a similar relationship could work between Western European and the later industrialised post-communist countries of Central Europe. Their comparative advantage has potentially freed up production capacities and led to lower production costs as well as their close proximity to markets at the turn of the 21 st century.

This article firstly examines the hypothesis that evolution brings about structural changes, the decline of older sectors and the promotion of new ones; shifting production from "older" to "new" sectors. It will examine the validity of the relationship between GDP and the four-sector structure as well as introducing an index of sector specialisation.

The theoretical introduction has led to justifying three clusters of research questions related to de-industrialisation and shifts in the secondary sector. It also allows a complex picture to be gained of the spatial patterns and dynamics of sectoral specialisation and concentration with a focus on manufacturing production and Central Europe:

1) What have the shifts been in secondary and knowledge-intensive sector employment in the European Union area (EU28) and fluctuations in the spatial concentration of industrial production over the past 20 years?

2) How does the sectoral specialisation of European countries relate to GDP per capita? Have advanced countries managed to regroup employment into a knowledge-intensive sector or for the most part into services?

3) To what extent does maintaining industrial production contribute to the vulnerability of external shocks? How has the secondary sector coped after the world crisis in 2007 ?

Hence, there are three main objectives of the paper which have been developed into separate sections of the paper:

- to identify the shifts in the secondary and knowledge-intensive sectors in the European Union area (EU28) over the past 20 years and the spatial concentrations of industrial production;

- to propose the novel Index of Sectoral Specialisation (ISS) and to examine and explain the structural and spatial shifts in the first two decades of the 21 st century, mainly driven by de-industrialisation and integration forces;

- to evaluate how the secondary sector coped with the world crisis in 2007 and assess the resilience of European economies.

\section{ECONOMIC SECTORS AND PATTERNS OF SPECIALISATION}

The study of primary, secondary, tertiary and quaternary economic activities has a long tradition in economic thinking. The primary sector represents the economic activities which handle natural resources. These range from agriculture to 
mining as well as the production or extraction of raw materials for industry. The secondary sector includes the manufacturing and assembly industries aimed at completing goods through the manufacturing or semi-manufacturing of raw materials. The tertiary sector comprises the services (intangible goods) to other businesses and consumers from retail to transportation. It is these three economic sectors which make up the traditional three-sector model in economics (Fisher 1939, Clark 1940 and Kuznets 1966). Prominent economists have paid considerable attention to sectoral-industrial issues also with regard to the importance of key sectors in various historical periods and thus to identifying stages of economic growth. Following the transition from an industrial to post-industrial society, the technological evolution has given rise to the notion of a "fourth sector" (quaternary sector). This latest sector reflects the knowledge-based part of the economy (Selstad 1990). The quaternary sector can be made up of economic activities such as finance, insurance, public administration and real estate activities (Kenessey 1987). Other definitions also include activities related to trading (Kellerman 1985), research and development, education and consulting (Selstad 1990). The formation of this sector highlights the importance and flow of information and knowledge as the economic sectors develop further. Knowledge has become critical due to the high demand for a skilled labour force which tends to be concentrated in specific areas (Dunning 2009, Isaksen and Onsager 2010 and Onsager et al. 2010). Thus, the rise of knowledge-intensive activities should be separated from the core of the tertiary sector.

The four sectors are sufficiently different to permit the separation and comparison of spatial units (Kenessey 1987). These are clearly assigned to the four main elements of the work process: extraction, processing, delivery and information. In this sense, the division into four sectors is advantageous for comparing countries or regions in time and space. Yet, it would be a mistake to consider the sectors as being independent of each other. The actions in one sector have impacts and consequences on other sectors, both positive and negative. There is extensive literature on the characteristics of the productive structure and regarding the various roles and importance of the sectors in the national and regional economy. While inputoutput models or network analysis provide analytical tools (Alatriste-Contreras 2015), these are beyond the scope of the current paper.

It is essential to understand the evolutionary economic shifts that took place in the second half of the 20th century in order to capture the current structural perspective at the beginning of the 21 st century. Changes in the sectoral structure cooccur with changes in the spatial distribution of economic activities. Industrial employment rates peaked in Western Europe around 1970 although they had already culminated earlier in some countries (the Netherlands, Switzerland, Sweden and the UK). The advanced economies found themselves in a post-industrial phase and de-industrialisation was set in motion (Rodrik 2016). Other countries started deindustrialisation as late as the 1990s (e.g. Portugal and Greece). Today, the employment share in services makes up more than half the employment in several Mediterranean countries (Greece, Cyprus and Spain). In comparison, the rapid growth in the quaternary sector is evident in the most developed countries.

A high geographical concentration of a specific industry suggests that a large amount of the overall share of that sector is concentrated in a few regions (Aiginger and Davies 2004 and Korec 2009). There are regions still heavily dependent on metal processing in Western Europe (e. g. the northern part of Spain, the southern 
regions of Sweden and the north of Finland) as well as in the CEE countries - the northeast of Czechia (the Moravian-Silesian Region) and East Slovakia. In terms of broader manufacturing (NACE Rev.2 section C), the two most specialised EU regions in manufacturing are in Slovakia (east and west), followed by the central region in Romania. Several German regions are also considered highly specialised in manufacturing (Johansson 2008). Hence, the structural shifts activated by deindustrialisation have not hit every region equally.

Modern theories consider the gradual integration of countries and economies of scale as essential drivers of specialisation (Krugman 1979). A firm is more likely to locate in a similar area where the industries and linkages are already welldeveloped as knowledge spill-overs tend to be localised (Glaeser 1998). The integration of European countries was also supposed to drive the process of continuous specialisation of regions (Krugman 1991 and Suedekum 2006). Economic activities tend to be concentrated near cities or in areas of high economic activity (Halás et al. 2014). Conversely, the drawback of narrow sectoral orientation is the risk of that particular sector declining as a result of a crisis (unexpected shock) or rapid technological advancement (Aiginger 2000 and Duranton and Puga 2000). Therefore, it makes sense to examine the changes in the economic structure of the EU countries and regions in more detail. In particular, the newer effects of deindustrialisation and impact of integration on the dynamics of changes in the geography of industrial production and economic resilience.

\section{THE CONTEXT OF THE CEE COUNTRIES}

The context of post-socialist countries in Central and Eastern Europe (CEE countries) is specific and structural changes are not in line with Western Europe (Rusnák and Lehocký 2016). Industrialisation used to be the engine of economic development within the framework of socialist central planning (Bachtler et al. 2001). The transition to advanced market economies after 1989 resulted in an economic downturn and loss of jobs. There are several declined old-industrial regions and urban areas which can be found in Poland, Czechia, Slovakia, Hungary, Romania and Bulgaria (Pammer 1997). The key issues facing them and their economic transformation in regional development after 1989 have been related to the unsustainably high proportion of employment in industry and agriculture. If regions fail to adapt to technological and societal changes and subsequently miss the sectoral shifts to knowledge-intensive industries, they will lag behind as a result of inappropriate sectoral structure. Despite gradual sectoral transformation, the primary and secondary sectors remain prominent in the CEE countries (Hudec and Prochádzková 2018). Slovakia and Czechia are the countries with the highest share of industrial employment and are among the leaders in the ever-increasing production of vehicles (Pavlínek and Žížalová 2014). The automotive sector has begun to dominate the secondary sector in these countries.

Car production has long been associated with the four "core" countries of the UK, France, Italy and Germany, which possess considerable knowledge and technological advancement. In between, the model of production has shifted from a domestic model to a model of global (network-based) production (Sturgeon and Florida 2000). The increasing price of labour has subsequently led to a shift of industrial production towards the CEE countries (Bungsche 2018) through privatisation and FDIs. The primary reason behind this was the challenge of cost-cutting, 
the lower production costs compared to Western Europe, the central location in Europe and stable economic situation. At the local level, other factors had already decided on the location of production - past production and the persistence of a skilled labour force (e.g. car producers KIA, Škoda, PSA, Volkswagen) as well as maintaining proximity to the final customers (Pavlínek et al. 2009). Although the CEE countries had previously experienced economic decline and a loss of employment in manufacturing, they have gained a temporary opportunity to maintaining secondary sector performance at about $30 \%$ of industrial employment thanks to their central location and dense network of suppliers (Domanski and Lung 2009).

Thus, the geographical shift of (mostly the automotive) industry to the CEE countries (particularly Slovakia, Czechia, Hungary and Poland) has had a shortterm positive impact on the employment levels in formerly lagging regions. This shift has helped to lower the unemployment rate as well as boost exports and productivity growth (Jakubiak et al. 2008). However, the risks of such an expansion have only recently begun to show. The new and unanticipated problem in Czechia and Slovakia has been the lack of a labour force. Thus, the only option for the car producers and suppliers has been importing workers from the southern Balkan countries.

\section{METHODOLOGY AND DATA}

The exploration of the economic structure of each country/region uses the classification of four sectors - primary, secondary, tertiary and knowledge-intensive (quaternary). The type of sectors follows the classification of economic activities as standardised by the Statistical classification of economic activities in the European Community (Eurostat 2015) and the International Standard Industrial Classification. The classification (Tab. 1) makes it possible to express the employment shares and distinguish the knowledge-intensive services (KIS) sector as a special division of employment. Each sector is subject to a geographical analysis showing the uneven distribution of employment in the countries and regions of the EU.

It could be assumed that more advanced countries allocate resources to higher sectors of the economy (Syrquin 2008, Hamilton 2017 and Van Neuss 2018). In order to examine this hypothesis, the authors have proposed the Index of Sectoral Specialisation (ISS) to evaluate the relationship between the advance of sectoral specialisation of a country and the GDP per capita within the interval $[-1,1]$. The ISS evaluates the sectoral specialisation of EU countries as follows: each sector (primary, secondary, tertiary, quaternary) is assigned equidistant values between -3 and 3, with the same increment as $S_{i}=-3,-1,1,3$, for $\mathrm{I}=1 \ldots 4$. If each sector is weighted by the percentage of employment in the country's total employment, the weighted average is located within the interval [-3.3]. In order to simplify the interpretations, normalisation is added to transform the overall result of the ISS into the interval $[-1.1]$. While positive values indicate the prevalence of tertiary and quaternary sectors, negative values indicate the predominance of the primary and secondary sectors. Boundary values would theoretically mean full employment in country c only in the primary sector $\left(I S S_{C}=-1\right)$, or solely in the quaternary sector $\left(I S S_{C}=1\right)$. The formula for country sectoral specialisation ISS is therefore expressed as

$$
I S S_{C}=\sum_{i=1}^{4} \frac{S_{i} E_{i}}{3.100} .
$$


Tab. 1. The scope and breakdown of the economic sectors. The classification of the four sectors based on Eurostat Nace rev.2 and several other approaches

\begin{tabular}{|c|c|c|}
\hline Economic sectors & Scope of economic activity & Economic activity \\
\hline Primary sector & Production of raw materials & Agriculture, forestry, and fishing; mining and quarrying \\
\hline Secondary sector & Manufacturing and industry & $\begin{array}{l}\text { Manufacturing; electricity, gas, steam and air conditioning } \\
\text { supply; water supply; sewerage, waste management and } \\
\text { remediation activities; construction }\end{array}$ \\
\hline Tertiary sector & Core services & $\begin{array}{l}\text { Wholesale and retail trade; repair of motor vehicles and } \\
\text { motorcycles; transportation and storage; accommodation } \\
\text { and food service activities; real estate activities; public } \\
\text { administration and defence; compulsory social security; } \\
\text { arts, entertainment, and recreation; other service activities } \\
\text { activities of households as employers; undifferentiated goods- } \\
\text { and services-producing activities of households for own use; } \\
\text { activities of extraterritorial organisations and bodies }\end{array}$ \\
\hline Quaternary sector & $\begin{array}{l}\text { Information services, } \\
\text { knowledge-intensive services } \\
\text { (KIS), knowledge-intensive } \\
\text { business services (KIBS) }\end{array}$ & $\begin{array}{l}\text { Information and communication; financial and insurance } \\
\text { activities; professional, scientific and technical activities; } \\
\text { administrative and support service activities; education; } \\
\text { human health and social work activities; high-tech knowledge- } \\
\text { intensive services; knowledge-intensive market services } \\
\text { (excluding financial intermediation and high-tech services); } \\
\text { knowledge-intensive financial services }\end{array}$ \\
\hline
\end{tabular}

Sources: Fisher (1939), Clark (1940), Fourastié (1945), Mallick (2015), Turečková and Martinát (2015) and Eurostat (2016a).

The calculation of spatial specialisation is evaluated by the Hoover-Balassa quotient (Hoover 1936). This measures the relative specialisation of the regions by comparing the share of employment in a given sector and region with the overall country share.

The specialisations of countries have changed considerably over the last few decades. The Modified Lilien Index (MLI) is applied to measure the change in the composition of regional employment shares (Eurostat 2019) between two time periods (1996 and 2016). The following formula is used to measure the structural shift, calculated for each EU country separately:

$$
\sigma=\sqrt{\left[\sum_{j=1}^{n} W_{j} \times\left(\ln \left(x_{j t} / x_{j s}\right)-\ln \left(X_{t} / X_{s}\right)\right)^{2}\right]},
$$

where $x_{j t}$ is sectoral employment in industry $j$ at the selected time ( $t$ and $s$ ) and $n$ is the number of industries/sectors. Similarly, $X_{t}$ represents the overall employment in the country at periods $t$ and $s$. Finally, $W_{j}$ denotes the average share of sector $j$ in overall employment for time periods $t$ and $s$. The sum of the MLI indicates the degree of structural change in a country within the economic sectors over twenty years. The values close to zero mean only small changes in the reallocation of employment among the sectors while higher values represent substantial structural changes in employment. 


\section{ECONOMIC AND SECTORAL DEVELOPMENT IN EUROPEAN COUNTRIES}

The first analysis concerns the structural changes in the EU economies. Tab. 2 provides a comparison of the structural patterns of EU countries - sectoral employment and ISS values in 1996 and 2016, as well as the degree of structural change as a value of MLI. Fig. 1 displays the share of employment in each sector. The ISS measures the degree of shift to higher sectors and the structural change index MLI measures the overall structural change between sectors in any direction. The MLI reflects the changes over the past 20 years, referring to substantial structural changes (highest MLI) in the catching up post-communist countries as well as Spain, Portugal and Ireland ${ }^{1}$.

The performance and growth of an economy are related to the allocation of resources among the sectors, although various combinations may show better overall performance under different circumstances. The primary sector is still relevant in the non-core EU countries such as the Balkan countries, Poland and Portugal. All other EU countries have experienced a significant decline in primary activities to value below $10 \%$. Unlike primary activities, industrial production cannot be considered a disappearing sector. In particular, Germany has had a unique sectoral approach (Audretsch and Lehmann 2016). Manufacturing makes up $12-13 \%$ of GDP in the USA or UK while in Germany it is almost twice as high at $21 \%$. While other industrialised countries have given up competing with Asia, Germany has been able to increase its exports to China and the rest of Asia. The tertiary service sector has a significant base in Western and South-Western Europe, especially in the Mediterranean. Employment in the service sector has been continuously increasing in absolute terms over the last three decades in Europe and also relative to industry.

There are substantial differences among the countries with higher employment rates in services (D'Agostino et al. 2006). While tertiary employment has grown comparatively rapidly in financial services, insurance, real estate and business services in the Netherlands, UK and Luxembourg. Greece, Spain and Austria have recorded an increase in employment in hotels, restaurants and the tourism subsectors. Belgium, Denmark, Finland, France and Sweden have shown a high relative increase in the community, social and health services. Thus, the reasons for employment growth in the tertiary sector are not all-encompassing and equal. The knowledge and innovation sector (KIS) follows a similar pattern to that of GDP per capita. The KIS drivers are the Netherlands, Belgium and the UK. The hypothesis of allocating resources to "higher" sectors of the economy can be confirmed on the basis of an analysis of sectoral distribution in relation to GDP per capita (Fig. 2).

The correlation chart confirms the shift of advanced economies towards the tertiary and quaternary sectors. Lower negative ISS values are related to lower GDP. The group of advanced countries (the UK, Belgium, Norway, Denmark and France) reach ISS index values between 0.4 and 0.5 . The comparatively highly industrialised Visegrad countries (Czechia, Hungary, Poland and Slovakia) are recognisable as a group with ISS values between 0.1 and 0.15 . The ISS values in 2016 were all found to be positive except for Romania, which still has employment le-vels of over $20 \%$ in the primary sector.

\footnotetext{
1 The list of two-letter country codes can be found here: https://ec.europa.eu/eurostat/statistics-explained/ index.php/Glossary:Country_codes
} 
GEOGRAFICKÝ ČASOPIS / GEOGRAPHICAL JOURNAL 73 (2021) 1, 21-41

Tab. 2. The sectoral employment in EU countries in 1996 and 2016

\begin{tabular}{|c|c|c|c|c|c|c|c|c|c|c|c|}
\hline \multirow[t]{2}{*}{ Country } & \multicolumn{2}{|c|}{$\begin{array}{l}\text { Primary sector } \\
\text { (in } \% \text { ) }\end{array}$} & \multicolumn{2}{|c|}{$\begin{array}{l}\text { Secondary sector } \\
\text { (in } \% \text { ) }\end{array}$} & \multicolumn{2}{|c|}{$\begin{array}{l}\text { Tertiary sector } \\
\text { (in } \%)\end{array}$} & \multicolumn{2}{|c|}{$\begin{array}{l}\text { Knowledge- } \\
\text { intensive sector } \\
\quad(\text { in } \%)\end{array}$} & \multicolumn{2}{|c|}{ ISS } & \multirow{2}{*}{$\begin{array}{c}\text { MLI*100 } \\
2016- \\
1996 \\
\end{array}$} \\
\hline & 1996 & 2016 & 1996 & 2016 & 1996 & 2016 & 1996 & 2016 & 1996 & 2016 & \\
\hline Austria & 4.27 & 4.10 & 27.52 & 22.31 & 44.81 & 44.97 & 20.19 & 28.61 & 0.19 & 0.32 & 24.66 \\
\hline Belgium & 2.34 & 1.32 & 24.29 & 17.55 & 46.45 & 42.86 & 26.91 & 38.27 & 0.32 & 0.45 & 26.78 \\
\hline Bulgaria & 23.89 & 18.72 & 29.15 & 24.61 & 35.03 & 39.36 & 11.93 & 17.31 & -0.10 & 0.04 & 21.29 \\
\hline Cyprus & 7.34 & 4.11 & 24.45 & 15.99 & 52.06 & 57.02 & 16.16 & 22.89 & 0.18 & 0.33 & 29.02 \\
\hline Czechia & 6.91 & 3.66 & 39.52 & 36.23 & 37.65 & 39.57 & 15.92 & 20.55 & 0.08 & 0.18 & 19.20 \\
\hline Germany & 2.56 & 1.54 & 30.59 & 24.08 & 42.81 & 40.93 & 24.04 & 33.45 & 0.26 & 0.38 & 23.02 \\
\hline Denmark & 4.13 & 2.58 & 23.03 & 16.86 & 42.01 & 43.57 & 30.83 & 36.92 & 0.33 & 0.43 & 19.58 \\
\hline Estonia & 11.11 & 4.32 & 31.92 & 28.27 & 40.89 & 45.04 & 16.08 & 23.46 & 0.08 & 0.25 & 32.39 \\
\hline Greece & 18.44 & 11.57 & 19.21 & 13.87 & 48.23 & 55.28 & 14.11 & 19.27 & 0.05 & 0.22 & 27.54 \\
\hline Spain & 7.56 & 4.15 & 27.56 & 17.60 & 47.96 & 52.82 & 16.92 & 25.42 & 0.16 & 0.33 & 33.7 \\
\hline Finland & 7.96 & 4.42 & 26.17 & 22.31 & 38.8 & 38.03 & 27.08 & 35.23 & 0.23 & 0.36 & 24.81 \\
\hline France & 4.42 & 2.81 & 21.66 & 16.71 & 44.76 & 43.90 & 29.16 & 36.59 & 0.32 & 0.43 & 19.45 \\
\hline Hungary & 9.56 & 6.17 & 32.04 & 25.99 & 43.66 & 44.38 & 14.73 & 23.46 & 0.09 & 0.23 & 31.35 \\
\hline Ireland & 10.54 & 5.71 & 26.42 & 17.54 & 39.17 & 44.09 & 23.87 & 32.71 & 0.18 & 0.36 & 31.76 \\
\hline Italy & 5.64 & 3.80 & 28.39 & 23.04 & 46.84 & 47.14 & 19.14 & 26.02 & 0.20 & 0.30 & 19.86 \\
\hline Lithuania & 20.71 & 8.18 & 25.69 & 24.91 & 39.79 & 46.77 & 13.81 & 20.14 & -0.02 & 0.19 & 40.23 \\
\hline Luxemburg & 2.56 & 0.94 & 30.30 & 18.90 & 42.93 & 35.20 & 24.21 & 31.75 & 0.26 & 0.36 & 30.89 \\
\hline Latvia & 14.89 & 7.90 & 24.52 & 22.40 & 44.53 & 47.91 & 16.15 & 21.78 & 0.08 & 0.22 & 25.67 \\
\hline Netherlands & 3.36 & 2.30 & 19.56 & 14.26 & 39.32 & 39.40 & 37.63 & 44.05 & 0.41 & 0.50 & 17.85 \\
\hline Poland & 22.98 & 11.98 & 27.86 & 29.67 & 36.29 & 39.97 & 12.87 & 18.38 & -0.07 & 0.10 & 31.38 \\
\hline Portugal & 14.78 & 9.74 & 32.46 & 22.56 & 37.12 & 43.71 & 15.64 & 24.00 & 0.02 & 0.21 & 32.47 \\
\hline Romania & 42.98 & 24.74 & 29.43 & 28.84 & 20.51 & 33.41 & 7.08 & 13.00 & -0.39 & -0.10 & 45.57 \\
\hline Sweden & 3.67 & 2.29 & 24.77 & 19.46 & 40.36 & 38.78 & 31.20 & 34.53 & 0.33 & 0.39 & 14.75 \\
\hline Slovenia & 14.22 & 8.00 & 37.18 & 28.86 & 32.73 & 36.77 & 15.87 & 26.38 & 0.00 & 0.21 & 33.81 \\
\hline Slovakia & 9.61 & 3.41 & 35.71 & 30.82 & 38.70 & 43.90 & 15.97 & 21.87 & 0.07 & 0.23 & 31.94 \\
\hline United Kingdom & 2.04 & 1.47 & 23.50 & 15.81 & 43.45 & 44.17 & 31.01 & 38.54 & 0.36 & 0.47 & 22.21 \\
\hline
\end{tabular}

Source: Eurostat (2016b), own elaboration. 

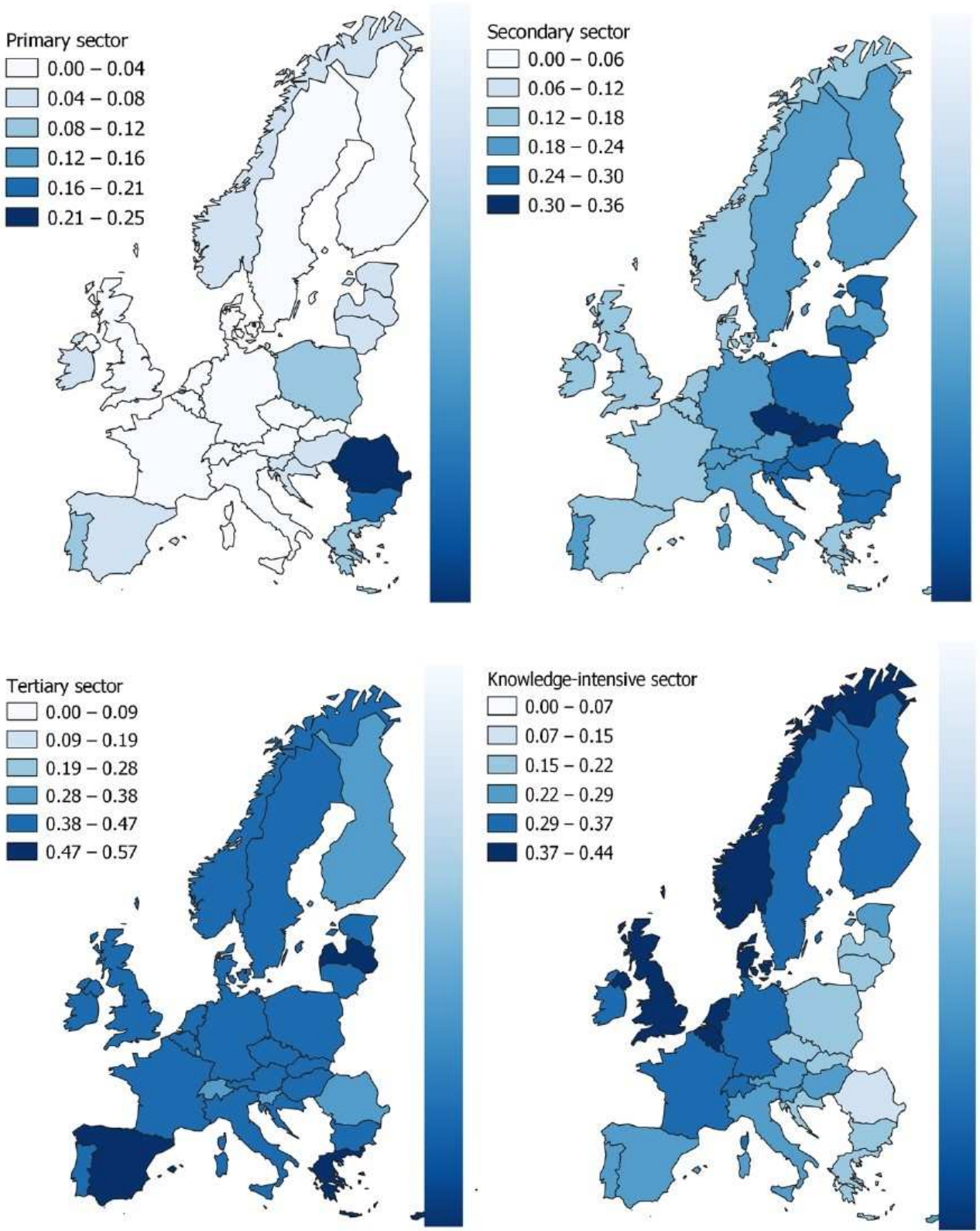

Fig. 1. Shares of employment in each economic sector in selected countries in 2016 (Primary sector; Secondary sector; Tertiary sector; Knowledge-intensive sector)

Source: Eurostat (2016b), own elaboration. 


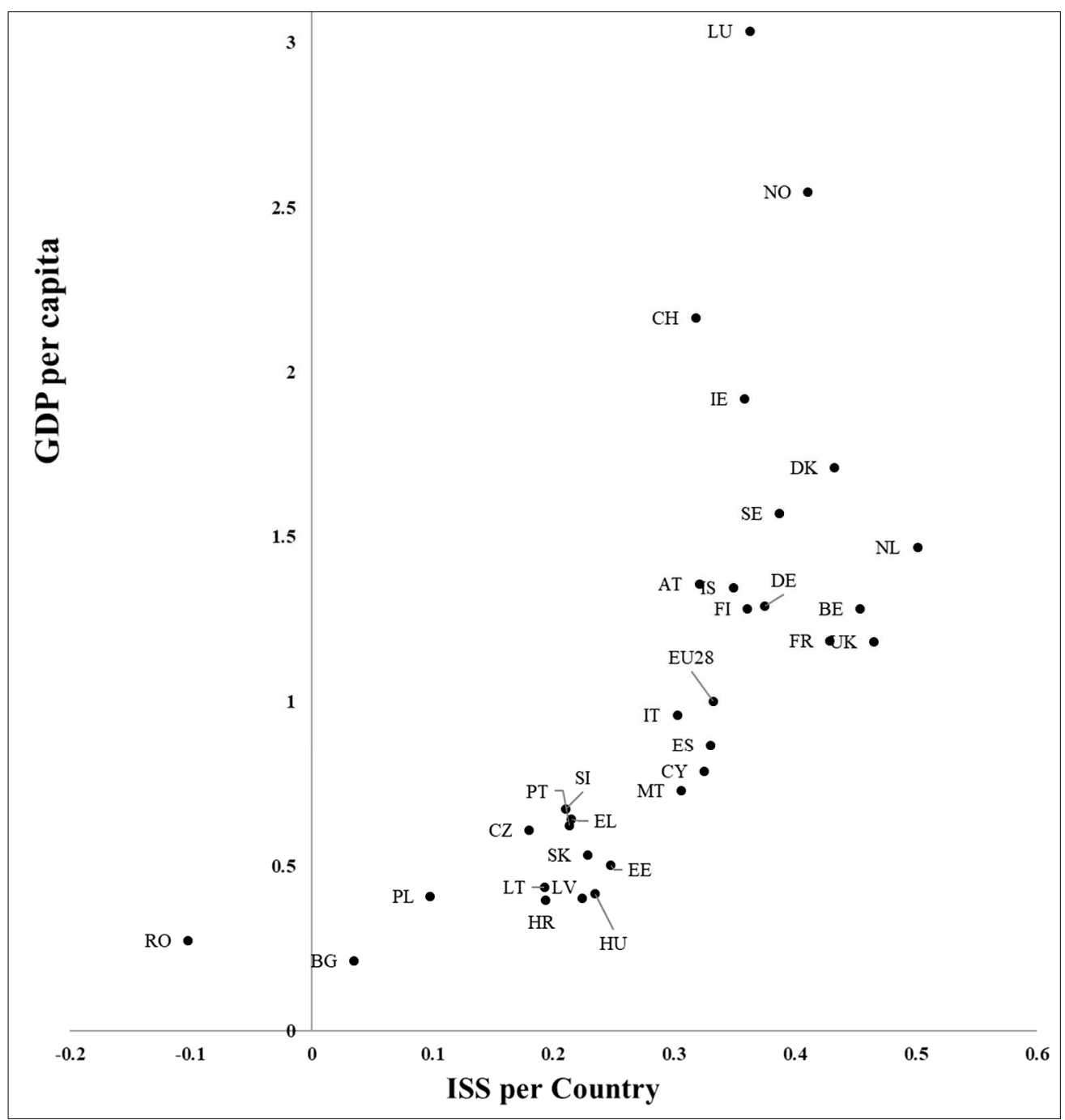

Fig. 2. ISS: Index of sectoral specialisation and GDP per capita (2016)

Source: own elaboration.

The move towards the tertiary and quaternary sectors is apparent when both the ISS values for 1996 and 2016 are compared (Tab. 2). The post-communist countries had mostly negative ISS values close to 0 or negative 20 years ago, and the structural change mainly occurred due to the slowdown in the primary sector. However, the Spearman rank correlation between ISS and GDP per capita was 0.62 in 2016 and 0.66 in 1996, respectively. This indicates a stable positive relationship between economic structure and production. 


\section{MANUFACTURING EMPLOYMENT IN EU REGIONS}

The secondary sector consists of Sections C to F of NACE Rev. 2 although section $\mathrm{C}$ - Manufacturing is the most focused in connection with de-industrialisation. Manufacturing includes a wide range of activities from small-scale traditional production to large production complexes producing cars or aircraft. Although a postindustrial shift towards the tertiary and quaternary sectors in European countries is apparent, there are spatial differences in manufacturing which are worth explaining. The aim is to provide a more detailed view of specialisation in manufacturing in smaller regional territorial units. The Hoover-Balassa quotient (or LQ - location quotient) can help identify the subtler differences and spatial patterns of manufacturing specialisation. The LQ is defined for region $i$ and sector $j$ as follows:

$$
L Q=\frac{\frac{x_{i j}}{\sum_{j} x_{i j}}}{\sum_{i} x_{i j}} .
$$

The values $x_{i j}$ stand for the employment of sector $j$ in region $i$. Hence, $\sum_{j} x_{i j}$ represents the total employment in all regions in sector $j$ and $\sum_{i} \sum_{j} x_{i j}$ represents the overall employment in all sectors and regions. The location quotient is a method of quantifying how concentrated a particular industry or sector is in a region compared to the whole country. It makes sense to consider the entire European Union instead of a country, so that specialisation is referred to as EU economic structure. The LQ has discovered the regions with the highest level of manufacturing concentration. The findings are displayed on the map with regards to the NUTS 2 regions (Fig. 3).

The regions in blue are those where the LQ values are higher than 1 . This corresponds to high manufacturing specialisation (as compared to EU28 total employment). Conversely, the regions marked in orange correspond to those with belowaverage employment in manufacturing. Certain regions in Germany as well as Central and Eastern Europe are those where the de-industrialisation process has stalled. The whole country of Czechia and most regions in Germany, Poland or Slovakia are specialised in manufacturing. There are some other regions, which still maintain their regional specialisation in the manufacturing industry (Northern Italy, Portugal, Spain, the UK, Ireland, Sweden, Finland, Estonia). Overall, manufacturing has been diminishing in the non-core regions of the European Union. However, there remains a coherent spatial concentration of industrial production that stretches from Germany to Romania and Bulgaria across the broad south-eastern arch.

The automotive industry has started to dominate manufacturing in Central Europe and will be briefly outlined. Automotive production represents $6.1 \%$ of total EU employment. In the last 25 years, CEE countries have become attractive for FDI expansion in the automotive industry as a result of the available industrial production knowledge. Besides this, their proximity to markets and economic stability have also been essential factors for FDI location (Frigant and Zumpe 2017). Central Europe has been turned into an interface between the Eastern and Western markets. The combination of different data sources has allowed us to calculate the share of the automotive sector in manufacturing employment. This includes the 
manufacturing of motor vehicles, trailers and semi-trailers (C29) as well as the manufacturing of body parts and accessories for the automotive industry. Fig. 4 demonstrates the concentration as well as the high share of employment in car production in the regions of Germany, Czechia, Slovakia, Hungary and Romania. Germany surpasses all other European countries in total car production, employing more than half a million workers in the automotive industry. Car production and employment are mostly situated in the border regions (Czech-Polish or GermanPolish borders). Germany has two major regions of car production in Bavaria and Baden-Wuerttemberg. In this location, there is an indispensable network of suppliers which are located along the Czech-German border. European integration is highly significant in terms of prosperity for the automotive industry through the spread of production from Germany, France and the United Kingdom to the CEE countries.

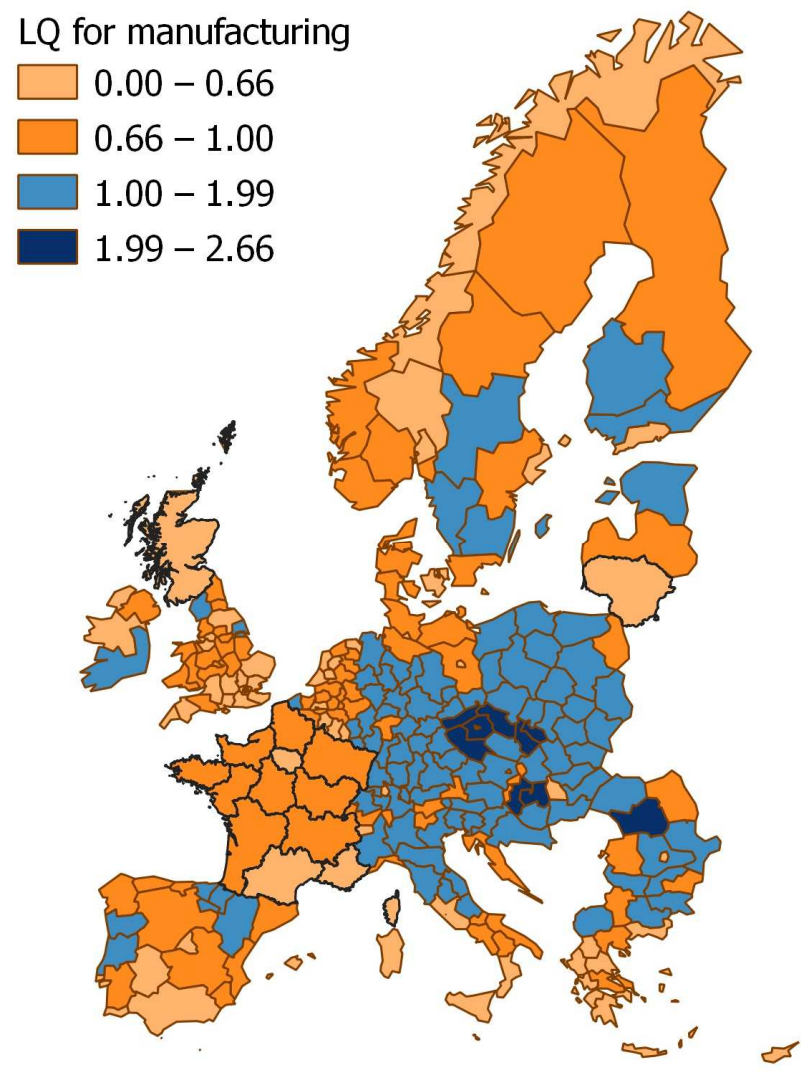

Fig. 3. Hoover Balassa quotient (LQ) values for manufacturing (C) Source: Eurostat (2016b), own elaboration. 


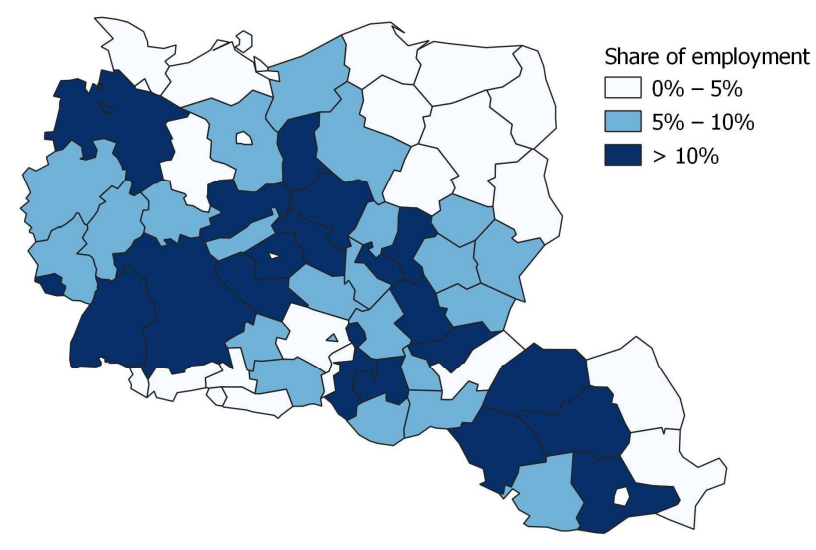

Fig. 4. Hoover Balassa quotient (LQ) for the manufacturing of motor vehicles, trailers and semi-trailers (Germany, Austria, Czechia, Slovakia, Hungary and Romania)

Source: Eurostat (2015), own elaboration.

\section{ECONOMIC STRUCTURE AND RESILIENCE}

It has been shown that the economic advancement of a country is significantly correlated to the economic structure set in higher sectors (tertiary and quaternary sectors). At the same time, some countries still maintain a higher level of manufacturing and do not follow the de-industrialisation precept in full. Therefore, a new research question can be posed as to what extent resilience to the global crisis is also related to the economic structure of a country or region. Since 2003, employment in industry in the EU-28 has been growing moderately in Central Europe (Fig. 5). Despite the financial crisis in 2007, employment levels still peaked in the first half of 2008 and then continued to decline by $21 \%$ in 2010 . A gradual revival then took place, and industrial employment gradually increased and regained more than 90 percent of its pre-crisis value by mid-2011. In the years 2011-2012, industrial employment was again on a slow downward trend, although the values had almost regained their pre-crisis level in Visegrad countries and Romania by 2013. The automotive industry was strongly hit by the 2007 crisis but appeared to emerge relatively quickly thanks to the rapid rise of car exports. It is the production of cars and other motor vehicles which makes up the most substantial part of the industry in employment, gross value added as well as in innovation.

The resilience of a regional economy is typically tested during the emergence of external shocks. Resilience theory provides a conceptual framework for understanding how and why regions differ in their ability to respond to this challenge. One of the factors is the economic structure of the regions and one comprehensible way is to verify resilience in the event of a global economic crisis and the time needed for recovery (Hudec 2017) as well as how fast it can bounce back. Following this, Fig. 6 displays how long it took regional GDP per capita to bounce back to the GDP levels before the crisis (2007). 


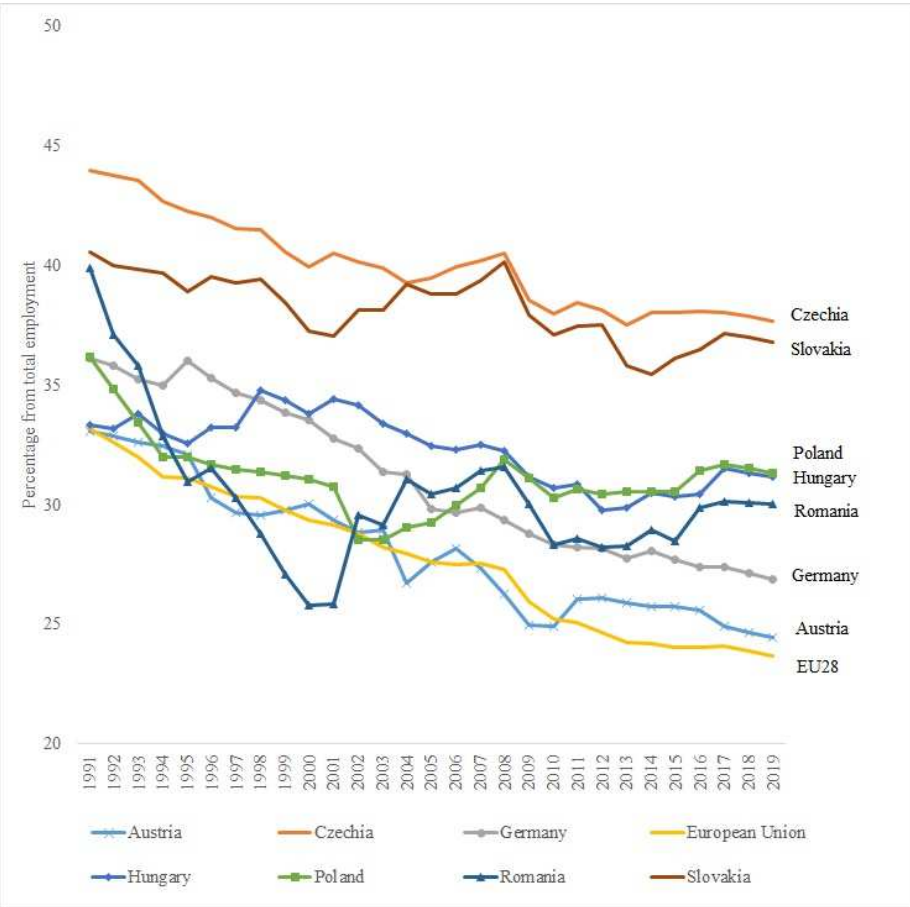

Fig. 5. Employment in industry $1991-2019$ (percentage of total employment) Source: World Bank (2019), own elaboration.

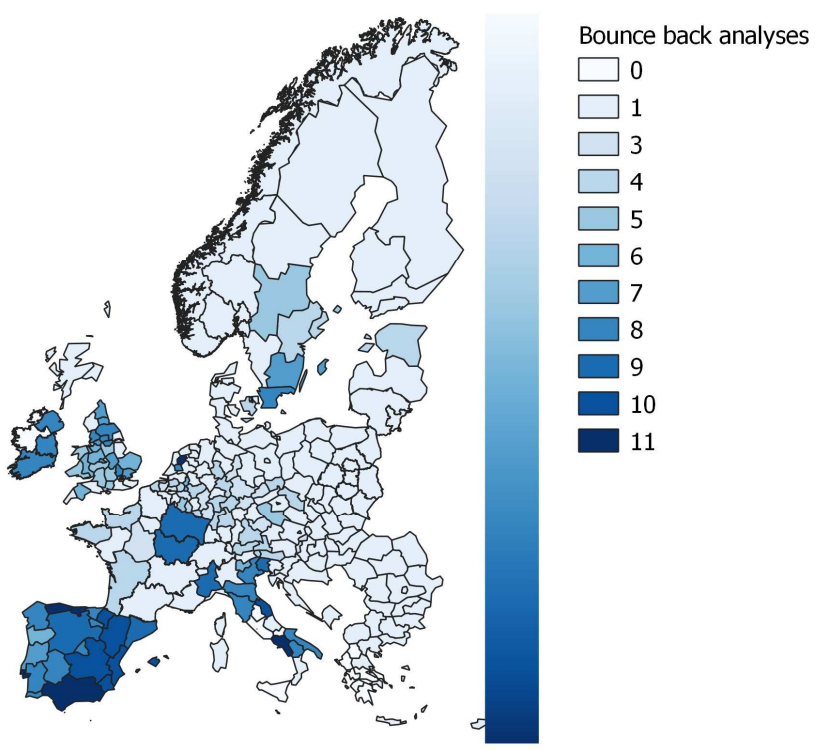

Fig. 6. Bounce back analysis $(2007-2018)$ Source: Eurostat (2018), own elaboration. 
Regional responses to the challenge of de-industrialisation vary. While some regions have undergone restructuring smoothly, others are still suffering due to a lock-in in the past industrial structure. The intensity of blue on the map stresses the time needed for the economy to recover in the European regions. The darker blue represents the most time needed in the region to recover from the financial crisis, whereas the lighter blue depicts the regions with faster recovery. The regions in Germany, Central and Eastern Europe have recovered more quickly compared to the regions of Western Europe (mainly regions of Spain). Several regions in Spain or Italy specialising in services were hit harder and needed significantly longer recovery times compared to more industrial or knowledge-intensive regions.

\section{CONCLUSIONS}

De-industrialisation has been a manifestation of the post-industrial era when jobs have increasingly moved from the primary and secondary sectors to services and knowledge-intensive sectors. The last two decades of economic growth have been characterised by the emergence of new jobs in the knowledge sector, particularly in advanced European economies. However, as confirmed in the analysis of data combined from several sources, the significance of the secondary sector is still evident in Central Europe. This delayed de-industrialisation progress in a relatively compact area in Central Europe is highly appealing to examine in terms of economic resilience.

Global post-industrial structural movements have a clear spatial dimension. It is assumed that the more developed the country is, the more significant the shift from the classical sectors (primary and secondary) to the knowledge-intensive sectors has been. The newly-created Sectoral Specialisation Index (ISS) has turned out to be a suitable tool for assessing structural changes and demonstrating their link to GDP. This has confirmed the hypothesis over the period 1996-2016 in the countries of the European Economic Area. The structural and spatial shifts in the economic structures of the EU countries and regions over the past 20 years justify the importance of focusing on the secondary and quaternary sectors. Despite the gradual de-industrialisation in Western Europe from the fifties onwards, Germany, Sweden, the Visegrad countries and Romania have maintained comparatively high levels of industrial employment, especially in the automotive industry. Several countries in Central Europe have stalled (albeit only temporarily) their decline in industrial employment. This is not a sign of delay in sectoral structure shifts, but rather a source of economic power. The integration of Europe has enabled favourable conditions for the spatial concentrations of production and suppliers on the borders between Western and Eastern Europe, operating in mutual symbiosis.

The ISS Index, in combination with the definition of the KIS as a sector, has the capacity to assess and explain the relationship between sectoral structure and the maturity of a country's measured GDP per capita. However, in order to see how specific countries are structurally changing, the Lilien Index can be modified. The structural change index (MLI) then allows us to estimate the rate of structural change in individual countries over 20 years in the European countries. The economic stability of the European Union depends on overcoming the economic disparities between the western and eastern parts. Therefore, detecting the spatial links that disrupt border logic and promoting interconnection and economic interplay is essential. 
Industry interacts very well with the quaternary sector driven by innovation. This combination allows leading European automotive industry countries to expand production at a reasonable cost, overcome emerging crises and generate employment in Central Eastern European countries. At the beginning of the 21 st century, automobile production was concentrated in the belt from Germany through the Visegrad countries to Romania and Bulgaria. The result of relocating automotive production from the traditional "homelands" can be observed in Central Europe. The Visegrad countries have experienced an enormous accumulation of automotive foreign direct investments (FDIs) and thus, rapidly increasing car production. However, FDIs have been criticised for a wide variety of reasons such as creating jobs out with the home country as well as the repatriation of profit in the FDI location.

The financial crisis (2008) hit the European economy significantly although recovery was surprisingly fast in some of them. The conducted bounce back analysis has shown how fast the European regions recovered from the global financial crisis. Central European and East European countries have shown the greatest economic resilience, with a focus on either KIS or industry. In other words, the countries with the highest specialisation in services have proven to be the most vulnerable and least resilient.

This work was supported by the project VEGA 1/0453/19.

\section{REFERENCES}

AIGINGER, K. (2000). Specialisation of European manufacturing. Austrian Economic Quarterly, 2, 81-92.

AIGINGER, K., DAVIES, S. W. (2004). Industrial specialisation and geographic concentration: Two sides of the same coin? Not for the European Union. Journal of Applied Economics, 7, 231-248. DOI: https://doi.org/10.1080/15140326.2004.12040610.

ALATRISTE-CONTRERAS, M. G. (2015). The relationship between the key sectors in the European Union economy and the intra-European Union trade. Journal of Economic Structures, 4, 14. DOI: https://doi.org/10.1186/s40008-015-0024-5.

ALDERSON, A. S. (1999). Explaining deindustrialization: Globalisation, failure, or success? American Sociological Review, 64, 701-721. DOI: https://doi.org/10.2307/ 2657372.

AUDRETSCH, D. B., LEHMANN, E. (2016). The seven secrets of Germany: Economic resilience in an era of global turbulence. New York (Oxford University Press).

BACHTLER, J., WISHLADE, F., YUILL, D. (2001). Regional Policy in Europe after enlargement. Glasgow (University of Strathclyde, European Policies Research Centre).

BUNGSCHE, H. (2018). Regional economic integration and the automobile industry: Automobile policies, division of labour, production network formation and market development in the EU and ASEAN. International Journal of Automotive Technology and Management, 18, 345-370.

CLARK, C. (1940). The conditions of economic progress. London (Macmillan).

D'AGOSTINO, A., SERAFINI, R., WARD-WARMEDINGER, M. E. (2006). Sectoral explanations of employment in Europe - the role of services. ECB Working Paper Series, Working paper 625. Frankfurt am Main (European Central Bank).

DOMAŃSKI, B., LUNG, Y. (2009). The changing face of the European periphery in the automotive industry. European Urban and Regional Studies, 16, 5-10. DOI: https:// doi.org/10.1177/0969776408098928.

DUNNING, J. H. (2009). Location and the multinational enterprise: A neglected factor\&quest. Journal of International Business Studies, 40, 5-19. DOI: http:// dx.doi.org/10.1057/jibs.2008.74. 
DURANTON, G., PUGA, D. (2000). Diversity and specialisation in cities: Why, where and when does it matter? Urban studies, 37, 533-555. DOI: https://doi.org/ $10.1080 / 0042098002104$.

Eurostat (2015). SBS data by NUTS 2 regions and NACE Rev. 2, [Online]. Available: http://appsso.eurostat.ec.europa.eu/nui/show.do?dataset=sbs_r_nuts06_r2\&lang=en [accessed 22 March 2019].

Eurostat (2016a). Glossary:Knowledge-intensive services (KIS), [Online]. Available: https://ec.europa.eu/eurostat/statistics-explained/index.php/Glossary:Knowledgeintensive services (KIS) [accessed 22 March 2019].

Eurostat (2016b). Employment $A * 10$ industry breakdowns, [Online]. Available: https:// appsso.eurostat.ec.europa.eu/nui/show.do?dataset=nama 10 a10_e\&lang=en [accessed 22 March 2019].

Eurostat (2018). SBS data by NUTS 2 regions and NACE Rev. 2, [Online]. Available: http://appsso.eurostat.ec.europa.eu/nui/show.do?dataset $=$ sbs_r_nuts06_r2\&lang=en [accessed 22 March 2019].

FISHER, A. G. B. (1939). Production, primary, secondary and tertiary. Economic record, 15, 24-38. DOI: https://doi.org/10.1111/j.1475-4932.1939.tb01015.x.

FOURASTIÉ, J. (1945). L'Économie française dans le monde. Paris (Presses Universitaires De France).

FRIGANT, V., ZUMPE, M. (2017). Regionalisation or globalisation of automotive production networks? Lessons from import patterns of four European countries. Growth and Change, 48, 661-681. DOI: https://doi.org/10.1111/grow.12207.

GEREFFI, G., HUMPHREY, J., STURGEON, T. (2005). The governance of global value chains. Review of International Political Economy, 12, 78-104. DOI: https:// doi.org/10.1080/09692290500049805.

GLAESER, E. L., KALLAL, H. D., SCHEINKMAN, J. A., SHLEIFER, A. (1992). Growth in cities. Journal of Political Economy, 100, 1126-1152. DOI: https://doi.org/ $10.1086 / 261856$.

HALÁS, M., KLAPKA, P., BLEHA, B., BEDNÁŘ, M. (2014). Funkčné regióny na Slovensku podla denných tokov do zamestnania. Geografický časopis, 66, 89-114.

HAMILTON, F. I., ed. (2017). Industrialization in developing and peripheral regions. New York (Routledge).

HALL, P. (1993). Forces shaping urban Europe. Urban Studies, 30, 883-898. DOI: https:// doi.org/10.1080/00420989320080831.

HERRENDORF, B., ROGERSON, R., VALENTINYI, Á. (2013). Growth and structural transformation. NBER Working Paper 18996. Cambridge, MA (National Bureau of Economic Research). DOI: https://doi.org/10.3386/w18996.

HOOVER, E. M. (1936). The measurement of industrial localization. The Review of Economic Statistics, 18, 162-171.

HUDEC, O. (2017). Cities of resilience: Integrated adaptive planning. Quality Innovation Prosperity, 21, 106-118. DOI: http://dx.doi.org/10.12776/qip.v21i1.776.

HUDEC, O., PROCHÁDZKOVÁ, M. (2018). The evolution of innovation networks in Slovakia: Disintegration and slow recovery. In Stejskal, J., Hájek, P., Hudec, O., eds. Knowledge spillovers in regional innovation systems. Cham (Springer), pp. 133-161. DOI: DOI: 10.1007/978-3-319-67029-4.

ISAKSEN, A., ONSAGER, K. (2010). Regions, networks and innovative performance: The case of knowledge-intensive industries in Norway. European Urban and Regional Studies, 17, 227-243. DOI: https://doi.org/10.1177/0969776409356217.

JAKUBIAK, M., KOLESAR, P., IZVORSKI, I., KUREKOVA, L. (2008.) The automotive industry in the Slovak Republic: Recent developments and impact on growth. World Bank Working Papers, Working Paper 57728. Washington (International Bank for Reconstruction and Development/The World Bank).

JOHANSSON, U. (2008). The main features of the EU manufacturing industry. Eurostat Statistics in focus, 37, 1-8. 
JORGENSON, D. W., TIMMER, M. P. (2011). Structural change in advanced nations: A new set of stylised facts. Scandinavian Journal of Economics, 113, 1-29. DOI: https:// doi.org/10.1111/j.1467-9442.2010.01637.x.

KELLERMAN, A. (1985). The evolution of service economies: a geographical perspective. The Professional Geographer, 37, 133-143. DOI: https://doi.org/10.1111/j.00330124.1985.00133.x.

KENESSEY, Z. (1987). The primary, secondary, tertiary and quaternary sectors of the economy. Review of Income and Wealth, 33, 359-385. DOI: https://doi.org/10.1111/ j.1475-4991.1987.tb00680.x.

KOREC, P. (2009). Štrukturálne zmeny ekonomiky Slovenska v prvej etape spoločenskej transformácie v regionálnom kontexte. Geographia Moravica, 1, 11-26.

KRUGMAN, P. (1979). Increasing returns, monopolistic competition, and international trade. Journal of International Economics, 9, 469-479. DOI: https://doi.org/10.1016/ 0022-1996(79)90017-5.

KRUGMAN, P. (1991). Increasing returns and economic geography. Journal of Political Economy, 99, 483-499. DOI: https://doi.org/10.1086/261763.

KUZNETS, S. (1966). Modern economic growth: Rate, structure, and spread. New Haven and London (Yale University Press).

LOW, P. (2013). The role of services in global value chains. In Elms, D. K., Patrick, L., eds. Global value chains in a changing world. Geneva (World Trade Organisation) pp. 61-81.

MALLICK, J. (2015). Quaternary sector and economic development in Japan: A causal analysis. Scientific Papers of the University of Pardubice - Series D, 23, 101-110.

ONSAGER, K., ASLESEN, H., GUNDERSEN, F., ISAKSEN, A., LANGELAND, O. (2010). City regions, advantages and innovation. NIBR reports, Report 5. Oslo (Norwegian Institute for Urban and Regional Research).

PAMMER, M. (1997). Proxy data and income estimates: The economic lag of central and eastern Europe. The Journal of Economic History, 57, 448-455. DOI: https:// doi.org/10.1017/S0022050700018520.

PAVLÍNEK, P., DOMAŃSKI, B., GUZIK, R. (2009). Industrial upgrading through foreign direct investment in Central European automotive manufacturing. European Urban and Regional Studies, 16, 43-63. DOI: https://doi.org/10.1177/0969776408098932.

PAVLINEK, P., ŽÍZZALOVÁ, P. (2014). Linkages and spillovers in global production networks: Firm-level analysis of the Czech automotive industry. Journal of Economic Geography, 16, 331-363. DOI: https://doi.org/10.1093/jeg/lbu041.

RODRIK, D. (2016). Premature deindustrialization. Journal of Economic Growth, 21, 1-33. DOI: https://doi.org/10.1007/s10887-015-9122-3.

RUSNÁK, J., LEHOCKÝ, F. (2016). Priestorová distribúcia a sektorová štruktúra priemyslu na Slovensku. Acta Geographica Universitatis Comenianae, 60, 69-102.

SELSTAD, T. (1990). The rise of the quaternary sector. The regional dimension of knowledge-based services in Norway, 1970 - 1985. Norsk Geografisk TidsskriftNorwegian Journal of Geography, 44, 21-37. DOI: https://doi.org/10.1080/ 00291959008552242.

STURGEON, T., FLORIDA, R. (2000). Globalization and jobs in the automotive industry. MIT-IPC Working Papers, Working Paper 00-012. Cambridge, MA (Center for Technology, Policy, and Industrial Development, Massachusetts Institute of Technology).

STURGEON, T., Van BIESEBROECK, J., GEREFFI, G. (2008). Value chains, networks and clusters: Reframing the global automotive industry. Journal of Economic Geography, 8, 297-321. DOI: https://doi.org/10.1093/jeg/lbn007.

SUEDEKUM, J. (2006). Concentration and specialization trends in Germany since reunification. Regional Studies, 40, 861-873. DOI: https://doi.org/10.1080/0034340 0600985087.

SYRQUIN, M. (2008). Structural change and development. In Dutt, A. K., Ros, J., eds. International handbook of development economics. Cheltenham (Edward Elgar), pp. 48-67. 
TAMURA, R. (2002). Human capital and the switch from agriculture to industry. Journal of economic Dynamics and Control, 27, 207-242. DOI: https://doi.org/10.1016/S01651889(01)00032-X.

TREGENNA, F. (2009). Characterising deindustrialisation: An analysis of changes in manufacturing employment and output internationally. Cambridge Journal of Economics, 33, 433-466. DOI: https://doi.org/10.1093/cje/ben032.

TUREČKOVÁ, K., MARTINÁT, S. (2015). Quaternary sector and extended sectoral structure of the economy in the selected European countries. Working Papers of the Silesian University, Working Paper 0010. Opava and Karviná (School of Business Administration).

Van NEUSS, L. (2018). Globalization and deindustrialization in advanced countries. Structural Change and Economic Dynamics, 45, 49-63. DOI: https://doi.org/10.1016/ j.strueco.2018.02.002.

World Bank (2019). Employment in industry (\% of total employment) (modeled ILO estimate), [Online]. Available: https://data.worldbank.org/indicator/SL.IND.EMPL.ZS [accessed 25 January2021].

Oto Hudec, Žofia Sinčáková

\section{ZMENY V SEKTOROVEJ ŠTRUKTÚRE A PRIESTOROVOM USPORIADANÍ V EURÓPE: KDE SA ZASTAVIL PROCES DEINDUSTRIALIZÁCIE?}

Súčasné zmeny v priestorovej distribúcii ekonomických aktivít boli stimulované vznikom globálnych hodnotových ret’azcov, ktoré významne pozmenili geografiu špecializácie od 90 . rokov 20. storočia. Zároveň zásadným spôsobom otriasol sektorovými profilmi regionálnych ekonomík paralelný efekt deindustrializácie, ked' sa postupne vyčerpal vyrovnaný rast produktivity priemyselnej výroby a zmenila sa štruktúra dopytu. Povojnový zlatý vek zamestnanosti v priemyselnej produkcii v západnej Európe postupne ustával na konci 60. rokov. Pracovné miesta v priemyselnej výrobe pomerne rýchlo musel nahradit' sektor služieb. Následne s prechodom k postindustriálnej spoločnosti priniesol technologický vývoj potrebu identifikácie štvrtého sektora, ktorý odráža znalostnú čast' ekonomiky.

V literatúre sa diskutovalo o rôznych faktoroch, ktoré spôsobujú deindustrializáciu vo vyspelých ekonomikách alebo k nej prispievajú - reklasifikácia pracovných miest $\mathrm{z}$ výroby na služby v dôsledku outsourcingových činností; pomalší rast zamestnanosti vo výrobe v dôsledku vyššieho rastu produktivity vo výrobe ako v službách; globalizácia a negatívne účinky medzinárodného obchodu, najmä dovozu od výrobcov s nižšími nákladmi. Fisher, Clark a Kuznets vo svojich dielach (Fisher 1939, Clark 1940 a Kuznets 1966) indikujú, že odvetvová štruktúra sa mení s vývojom ekonomík. Odvetvia s rastúcim podielom agregovanej výroby koexistujú s upadajúcimi odvetviami a každé odvetvie prechádza cyklom rastu, vyspelosti a stagnácie. Vyspelejšie krajiny sú tiež na čele inovácií a prechádzajú štrukturálnymi zmenami skôr ako menej rozvinuté.

Štvrtý sektor výroby náročnej na znalosti sa preto v článku používa na rozšírenie trojsektorového modelu ekonomiky a navrhuje sa index sektorovej špecializácie (ISS). Ten umožňuje vysvetlit' a empiricky overit' hypotézu o vzt'ahu medzi sektorovou štruktúrou a hrubým domácim produktom. ISS bol navrhnutý s ciel'om overit' hypotézu, že vyspelejšie krajiny alokujú zdroje do vyšších sektorov. Empiricky sme overili opodstatnenost' vytvorenia štvrtého sektora a evolúciu od starších k novým sektorom inovačne podnecovanú vyspelejšími krajinami.

Pritom však priemyselný sektor nemusí byt' upadajúci ani vo vyspelých ekonomikách napriek polstoročiu prebiehajúcej deindustrializácii. V období postupnej deindustrializácie v Európe si Nemecko, Švédsko, krajiny Vyšehradskej štvorky a Rumunsko zachovávajú pomerne vysokú úroveň zamestnanosti v priemyselnej výrobe, najmä v automobilovom 
priemysle. Existujú regióny v Nemecku aj v strednej a východnej Európe, kde sa proces deindustrializácie pozastavil. A jedným z pozitív udržiavania priemyselnej výroby môže byt' aj menšia zranitel'nost' voči globálnym externým šokom. Empiricky preto skúmame čas potrebný na návrat hodnoty regionálneho HDP na obyvatel'a spät' na úroveň spred krízy v roku 2007. Regióny v Nemecku a strednej i východnej Európe sa zotavili rýchlejšie v porovnaní s inými regiónmi Európy. Viaceré oblasti v Španielsku alebo v Taliansku so špecializáciou na služby boli zasiahnuté silnejšie a v porovnaní s priemyselne náročnejšími alebo znalostne náročnejšími regiónmi potrebovali podstatne dlhší čas na zotavenie. 
